\title{
Ibm - Penguatan Nilai Tambah Ekonomi Masyarakat Desa Melalui Pengembangan Produk Pangan Olahan Berbasis Kentang (Potatoes) Di Dusun Klandungan, Desa Landungsari, Kecamatan Dau Kabupaten Malang
}

\author{
${ }^{1}$ Agung Prasetyo Nugroho Wicaksono, ${ }^{2}$ Aris Soelistyo \\ ${ }^{1,2}$ Universitas Muhammadiyah Malang, Jl Raya Tlogomas No. 246 Tlogomas, Babatan, Tegalgondo, \\ Kec. Lowokwaru, Kota Malang, Jawa Timur \\ Email:'1agungpnw@umm.ac.id; '2aris_s@umm.ac.id
}

\begin{abstract}
Efforts to increase community income to increase the ability to process potato-based food, potato donuts food to become a potential independent entrepreneur, and increase the family stage will also impact the development of diversification of nutritious food products based on local wisdom. This community service program serves to develop the potential of the people of Landungsari Village, Dau District, Malang Regency in developing potato-based processed food products into nutritious "Potato Donuts" and is expected to increase the income of the village community.This community service activity was carried out by providing hands-on training in making potato-based processed food products into potato donuts. The output of this activity is in the form of SOPs for making potato donuts and standard national publication journals. The service method is carried out with an extension approach and direct practice on the spot.
\end{abstract}

Keywords: Potatoes, Potato Doughnut

Abstrak. Upaya peningkatan pendapatan masyarakat pedesaan melalui penguatan kemampuan olah pangan berbasis kentang menjadi produk pangan donat kentang menjadi wirausaha mandiri yang potensial, selain menambah penghasilan keluarga juga akan berdampakpada pengembangan diversifikasi produkpanganyang bergizi dan berbasis kearifan lokal. Program pengabdian masyarakat ini ditujukan sebagai upaya pengembangan potensi masyarakat desa Landungsari, Kecamatan Dau, Kabupaten Malang di dalam mengembangkan produk olahan pangan berbasis kentang menjadi "Donat Kentang" yang bergizi dan diharapkan mampu meningkatkan pendapatan masyarakat desa. Kegiatan Pengabdian ini dilakukan dengan memberikan pelatihan praktik langsung pembuatan produk makan olahan berbasis kentang menjadi donat kentang. Luaran dari kegiatan ini berupa SOP pembuatan donat kentang, serta jurnal publikasi nasional terstandar. Metode pengabdian dilakukan dengan pendekatan penyuluhan dan praktik langsung di lapangan.

Kata Kunci: Kentang, Donat Kentang

\section{Pendahuluan}

\section{Analisis Situasi}

Peranan wanita dalam proses penguatan ekonomi rumah tangga menjadi penting dan strategis (Huriani et al., 2021), khususnya pada bidang penguatan dan diversifikasi pangan (Ihsan et al., 2021; Kurnianingsih et al., 2021; Kusmayadi et al., 2021; Wicaksono \& Soelistyo, 2020). Demikian pula dengan desa Landungsari untuk dusun Klandungan Kecamatan Dau, dimana para ibu rumah tangga sebahagian besar 
hidup bercocok tanam membantu suami dalam mengelola lahan yang dimiliki untuk ditanami tanaman yang menjadi basis penyokong kuat ekonomi rumah tangga. Namun, karena kehidupan pada sektor pertanian, ditandai dengan waktu tunggu yang relatif lama antara masa tanam dan panen, sehingga optimalisasi penggunaan waktu tunggu itu dapat bermanfaat menghasilkan nilai tambah untuk penguatan ekonomi keluarga.

Secara geografis, Luas lahan untuk pertanian 83 ha yang terdiri atas: Sawah irigasi teknis 53 ha dan 30 ha sawah tadah hujan. Luas tanah tegalan 141 ha, pemakaman umum 5 ha, dan untuk perkantoran, sekolahan dan lapangan serta jalan sekitar 9 ha, serta untuk aktivitas ekonomi sebesar 0,7 ha (Syairozi, 2021). Kondisi yang demikian menjadi potensial untuk tanaman palawija (seperti kacang tanah, kacang panjang, buncis, ubi jalar (kentang), dan juga tanaman tebu, serta buah-buahan yang mampu menjadi sumber pendapatan menjanjikan bagi arga desa di sektor pertanian, termasuk juga tanaman sayuran (seperti cabe merah, brungkul, kentang manis, tomat, dan lainya) sangat memberikan harapan bagi masyarakat pedesaan.

Dusun Klandungan berada paling selatan wilayah Landungsari, dari segi perekonomian masih sedikit tertinggal dari dua dusun lainnya (Dusun Bendungan dan Dusun Rambaan). Masyarakatnya sebagaian masih bekerja dalam bidang pertanian, sebagian pegawai negeri, dan pedagang. Wilayahnya sangat luas, seiring dengan perkembangan masyarakat banyak juga pengembang membangun perumahan di dusun Klandungan. Distribusi pemetaan penduduk berbasis pekerjaan lebih banyak didominasi dengan pekerjaan Tukang kayu/batu, petani dan buruh tani, pegawai negeri sipil dan peternak, dengan pendapatan yang senantiasa fluktuasi dan sekadar cukup memenuhi kebutuhan hidup.

Aktivitas ibu ibu rumah tangga yang terkoordinasi pada berbagai dasa wisma menjadi strategis untuk diberikan penguatan, pengetahuan, dan pemahaman perihal penguatan ketahanan dan diversifikasi pangan yang mampu mendukung penguatan ekonomi keluarga (Syarifuddin et al., 2020). Selain itu, pengunaan waktu senggang para ibu rumah tangga dapat teralokasi lebih produktif dengan menghasilkan aneka produk pangan yang bergizi. Kesibukan yang dimanfaaatkan untuk hal produktif juga dapat mengurangi angka kelahiran yang pada akhirnya menguatkan program keluarga berencana.

Penguatan ketahanan pangan menjadi strategis melalui ketersediaan pangan, akses terhadap pangan dan penghasilan, pemanfaatan atau penyerapan pangan, serta kerentanan pangan (Santosa, 2021). Ketersediaan pangan diukur dari besaran konsumsi per kapita normatif dibandingkan dengan ketersediaan bersih pangan (Fitrianingrum \& Aulia, 2018; Syarifuddin et al., 2020). Faktor akses terhadap pangan dan penghasilan, diukur dari berapa persentase orang miskin dan persentase orang yang bekerja kurang dari 15 jam per minggu, persentase orang yang tidak tamat sekolah dasar, serta persentase rumah tangga dengan akses listrik. Memanfaatkan kegiatan para ibu rumah tangga yang tergabung dalam Dasa Wisma menjadi hal penting dan strategis untuk memberikan penguatan pemahaman perihal ketahanan dan penguatan pangan.

Selain itu, melalui kegiatan dasa wisma pada ibu rumah tangga pedesaan akan menguatkan angka faktor penyerapan pangan berkaitan dengan peningkatan harapan hidup anak berumur satu tahun, gizi balita, pengurangan persentase buta huruf, pengurangann persentase anak yang tidak diimunisasi. Demikian pula, dengan faktor kerentanan pangan melalui kegiatan dasa wisma dapat didorong pemanfaatan lahan pertanian untuk tanaman multi produk, 
bukan hanya padi, namun juga bisa ditanam kentang yang bernilai gizi, serta penguatan keaneka ragaman pangan berbasis pada tanaman kentang.

Frekuensi pertemuan para ibu rumah tangga yang tergabung pada kelompok dasa wisma menjadi sarana efektif untuk memberikan penyuluhan tentang pentingnya penguatan dan diversifikasi pangan, serta pemanfaatan lahan lahan yang kosong untuk ditanam kentang, sehingga kentang menjadi produk ungggulan masyarakat desa serta penguatan pemenuhan gizi dan menjadikan sumber ekonomi rumah tangga petani bila diinginkan untuk dikembangkan menjadi unit usaha baru yang produktif bagi upaya meningkatkan nilai tambah ekonomi petani.

\section{Permasalahan Mitra}

Permasalahan utama mitra, berkaitan dengan dasar kehidupan berbasis pada sektor pertanian, dimana waktu tunggu antara masa tanam dan panen cukup lama, sehingga diperlukan kreativitas dan produktivitas untuk mengisi peluang waktu tunggu tersebut, diisikan dengan kegiatan produktif, baik sebagai upaya peningkatan pendapatan maupun upaya diversifikasi produk makanan. Dalam hal ini pembuatan wirausaha donat kentang yang diberikan pada kelompok dasa wisma.
Rangkuman interaksi komponen hasil SWOT untuk ranah kondisi masyarakat pedesaan di Desa Landungsari, Kecamatan Dau, Kabupaten Malang dapat disajikan melalui Tabel 1 sebagai berikut.

\section{Permasalahan dan Isu-Isu Strategis}

Berdasarkan evaluasi diri yang berkaitan dengan pengembangan produk pangan olahan kentang menjadi produk pangan unggulan, tentunya berkaitan dengan dinamisasi perkembangan teknologi pangan dan digital marketing serta perkembangan keuangan mikro, namun semuanya masih belum sepenuhnya masuk pada pedesaan. Permasalahan tersebut dapat dikelompokkan kedalam tiga kelompok akar permasalahan, yaitu permasalahan kualitas produk pangan dan proses pengolahan pangan yang memerlukan konsistensi, keajegan, dinamisasi dari waktu ke waktu. Oleh karena itu, kebaruan harus diprioritaskan dengan mengembangkan sejumlah research dan pengabdian yang mengedepankan perkembangan pengolahan produk pangan yang berkembang seiring dengan perkembangan perilaku manusia dalam lingkup uncertainty dan ekspektasi rasional serta spekulasi, kurangnya inovasi pendidikan pengolahaan pangan serta teknologi pasca panen untuk petani.

Tabel 1. Rencana pengembangan strategi pengabdian berbasis analisis SWOT di Desa Landungsari, Kecamatan Dau, Kabupaten Malang

\begin{tabular}{|c|c|c|c|}
\hline Kekuatan & Kelemahan & Peluang & Ancaman \\
\hline $\begin{array}{l}\text { a. Kuatnya semangat } \\
\text { kerja para petani } \\
\text { yang tekun dan } \\
\text { sabar. } \\
\text { b. Kuatnya semangat } \\
\text { kerjasama } \\
\text { gotong royong } \\
\text { pada masyarakat } \\
\text { pedesaan } \\
\text { c. Religius dan } \\
\text { silahturahmi yang } \\
\text { cukup kuat. } \\
\text { d. Terbuka atas } \\
\text { informasi dan } \\
\text { pengetahuan baru. }\end{array}$ & $\begin{array}{l}\text { a. Minimnya pengetahuan } \\
\text { petani/masyarakat desa } \\
\text { perihal pengolahan pangan. } \\
\text { b. Lemahnya kepedulian akan } \\
\text { pentingnya bercocok tanam } \\
\text { kentang. } \\
\text { c. Masih belum optimalnya } \\
\text { penggunaan lahan. } \\
\text { d. Belum kuatnya pemahaman } \\
\text { pengolahan produk pangan } \\
\text { berbasis kentang. } \\
\text { e. Banyaknya waktu luang } \\
\text { fang tidak dimanfaatkan. } \\
\text { f. Belum optimal kreativitas } \\
\text { diversifikasi produk pangan. }\end{array}$ & $\begin{array}{l}\text { a. Banyaknya program } \\
\text { corporate social } \\
\text { responcibility yang } \\
\text { hadir. } \\
\text { b. Banyaknya kegiatan } \\
\text { program pengabdian } \\
\text { masyarakat baik } \\
\text { dari Universitas atau } \\
\text { institusi lainnya. } \\
\text { c. Tuntutan masyarakat } \\
\text { dan Pemerintah } \\
\text { Daerah terhadap hasil } \\
\text { produk unggulan } \\
\text { daerah. }\end{array}$ & $\begin{array}{l}\text { a. Banyaknya produk } \\
\text { pangan impor yang } \\
\text { memasuki pasar } \\
\text { domestik. } \\
\text { b. Lemahnya teknologi } \\
\text { pasca panen. } \\
\text { c. Banyaknya pemuda/ } \\
\text { tenaga kerja yang } \\
\text { enggan bekerja di } \\
\text { sektor pertanian. } \\
\text { d. Makin menurunnya } \\
\text { luas areal tanam } \\
\text { untuk pertanian yang } \\
\text { beralih fungsi menjadi } \\
\text { perumahan dan } \\
\text { industri. }\end{array}$ \\
\hline
\end{tabular}


Tabel 2. Masalah dan akar permasalahan masyarakat di Desa Landungsari, Kecamatan Dau, Kabupaten Malang

\begin{tabular}{|c|c|c|c|c|c|c|c|c|}
\hline \multicolumn{2}{|r|}{ Permasalahan } & \multirow{2}{*}{ Akar Permasalahan } & \multicolumn{6}{|c|}{ Isu-Isu Strategis } \\
\hline No & Keterangan & & $\mathbf{L}$ & $\mathbf{R}$ & $\mathbf{A}$ & I & $\mathbf{S}$ & $\mathbf{E}$ \\
\hline 1 & 2 & 3 & 4 & 5 & 6 & 7 & 8 & 9 \\
\hline 1 & $\begin{array}{l}\text { Tingginya waktu senggang petani } \\
\text { antara tanam dan waktu panen }\end{array}$ & \multirow{3}{*}{$\begin{array}{l}\text { Kurang kuatnya penguasaan atau } \\
\text { pemahaman ilmu pengolahan pangan, } \\
\text { khususnya pengolahan pangan berbasis } \\
\text { produk kentang }\end{array}$} & $\mathrm{x}$ & $\mathrm{x}$ & $\mathrm{x}$ & $\mathrm{x}$ & $\mathrm{x}$ & $\mathrm{x}$ \\
\hline 2 & $\begin{array}{l}\text { Lemahnya perhatian kelembagaan } \\
\text { desa untuk pengembangan produk } \\
\text { pangan kentang olahan sebagai } \\
\text { Produk Unggulan Olahan Pangan } \\
\text { Pedesaan yang strategis }\end{array}$ & & $\mathrm{x}$ & $\mathrm{x}$ & $\mathrm{x}$ & $\mathrm{x}$ & $\mathrm{x}$ & \\
\hline 3 & $\begin{array}{l}\text { Minimnya pengetahuan petani } \\
\text { untuk diversifikasi pangan dan } \\
\text { keaneka ragaman produk pangan }\end{array}$ & & $\mathrm{x}$ & $\mathrm{x}$ & $\mathrm{x}$ & $\mathrm{x}$ & $\mathrm{x}$ & $\mathrm{x}$ \\
\hline 4 & $\begin{array}{l}\text { Minimnya Pengetahuan Kadar Gizi } \\
\text { produk olahan pangan kentang } \\
\text { dan lemahnya kesadaran untuk } \\
\text { menaikkan nilai tambah ekonomi } \\
\text { bagi masyarakat desa }\end{array}$ & $\begin{array}{l}\text { Kurangnya inovasi rekayasa pangan } \\
\text { yang bergizi dan menguatkan-nya nilai } \\
\text { tambah pendapatan masyarakat desa }\end{array}$ & $\mathrm{x}$ & $\mathrm{x}$ & $\mathrm{x}$ & $\mathrm{x}$ & $\mathrm{x}$ & $\mathrm{x}$ \\
\hline
\end{tabular}

Masih belum optimalnya peran desa dan Bulog dalam menangani produk petani saat panen, dimana harga produk petani saat panen yang rendah karena tidak adanya bulog, khususnya kentang yang harganya anjlok saat panen. Disisi lain, pemasaran kentang hanya ditujukan untuk pakan ternak, padahal kandungan Gizi untuk produk kentang sangat tinggi dan strategis untuk pemenuhan gizi masyarakat pedesaan, dikuatkan lagi bilamana produk pangan tersebut dapat ditransformasi bentuknya menjadi pangan olahan, misalnya dari kentang menjadi nugget dan donat kentang yang tentunya akan bernilai gizi tinggi serta menjadi sumber wirausaha baru yang menjanjikan dan menaikan nilai pendapatan masyarakat. Ringkasan masalah dan akar permasalahan tertera pada Tabel 2 .

\section{Strategi Pemecahan Masalah}

Berdasarkan fenomena/gejala dan akar permasalahan yang ditemukan dengan mengacu pada data yang dikumpulkan, maka diajukan beberapa alternatif strategi penyelesaian masalah seperti tertera pada Tabel 3.

Secara spesifik telah diprioritaskan

Tabel 3. Strategi yang Dilakukan untuk Mengatasi Akar Permasalahan yang Berhasil Diidentifikasi

\begin{tabular}{|c|c|c|c|}
\hline \multicolumn{2}{|r|}{ Gejala/Fenomena Masalah } & \multirow{2}{*}{ Akar Permasalahan } & \multirow{2}{*}{$\begin{array}{c}\text { Strategi pelaksanaan } \\
\text { kegiatan yang akan } \\
\text { dilakukan }\end{array}$} \\
\hline No & Keterangan & & \\
\hline 1 & 2 & 4 & 5 \\
\hline 1 & $\begin{array}{l}\text { Tingginya waktu senggang petani antara tanam dan } \\
\text { waktu panen }\end{array}$ & \multirow{3}{*}{$\begin{array}{l}\text { Kurang kuatnya } \\
\text { penguasaan atau } \\
\text { pemahaman ilmu } \\
\text { pengolahan pangan, } \\
\text { khususnya pengolahan } \\
\text { pangan berbasis produk } \\
\text { kentang }\end{array}$} & \multirow{3}{*}{$\begin{array}{l}\text { Peningkatan Penguatan } \\
\text { Keilmuan masyarakat } \\
\text { desa terhadap } \\
\text { pengolahan produk } \\
\text { pangan kentang }\end{array}$} \\
\hline 2 & $\begin{array}{l}\text { Lemahnya perhatian kelembagaan desa untuk } \\
\text { pengembangan produk pangan kentang olahan } \\
\text { sebagai Produk Unggulan Olahan Pangan Pedesaan } \\
\text { yang strategis }\end{array}$ & & \\
\hline 3 & $\begin{array}{l}\text { Minimnya pengetahuan petani untuk diversifikasi } \\
\text { pangan, dan keaneka ragaman produk pangan }\end{array}$ & & \\
\hline 4 & $\begin{array}{l}\text { Minimnya Pengetahuan Kadar Gizi produk olahan } \\
\text { pangan kentang dan lemahnya kesadaran untuk } \\
\text { menaikkan nilai tambah ekonomi bagi masyarakat } \\
\text { desa }\end{array}$ & $\begin{array}{l}\text { Kurangnya inovasi } \\
\text { rekayasa pangan yang } \\
\text { bergizi dan penguatan } \\
\text { nilai tambah pendapatan } \\
\text { masyarakat desa }\end{array}$ & $\begin{array}{l}\text { Perlunya rekayasa } \\
\text { produk pangan kentang } \\
\text { menjadi produk Donat } \\
\text { Kentang }\end{array}$ \\
\hline
\end{tabular}


Tabel 4. Beberapa Permasalahan Mitra Dalam Kenekaragaman Produksi Pangan Olahan Kentang

\begin{tabular}{ll}
\hline \multicolumn{1}{c}{ Problem Mitra } & \multicolumn{1}{c}{ Solusi } \\
\hline $\begin{array}{l}\text { Keterbatasan pengetahuan Mitra dalam pengolahan } \\
\text { diversifikasi pangan berbasis kentang }\end{array}$ & $\begin{array}{l}\text { Pemberi sejumlah pelatihan/praktik langsung pembuatan } \\
\text { produk pangan }\end{array}$ \\
\hline $\begin{array}{l}\text { Mitra belum dapat membuat pengembangn produk } \\
\text { pangan kentang untuk menjadi donut kentang }\end{array}$ & $\begin{array}{l}\text { Dilakukan penyuluhan praktik langsung ke lapangan } \\
\text { pembuatan donut kentang }\end{array}$ \\
\hline Mitra belum menguasai pembuatan kue donat kentang & $\begin{array}{l}\text { Pelatihan dan praktik langsung pembuatan kue donat } \\
\text { kentang }\end{array}$ \\
\hline $\begin{array}{l}\text { Belum mengetahui nilai kandungan gizi dari produk } \\
\text { pangan berbasis kentang }\end{array}$ & $\begin{array}{l}\text { Perlu pengetahuan untuk dapat menilai berapa nilai } \\
\text { gizi setiap produk pangan yang dibuat atau diproduksi } \\
\text { berbasis kentang }\end{array}$ \\
\hline $\begin{array}{l}\text { Belum mengetahui metode Pemasaran produk pangan } \\
\text { olahan kentang }\end{array}$ & $\begin{array}{l}\text { Perlu mengetahui berbagai macam teknik pemasaran dari } \\
\text { produksi yang dibuat }\end{array}$ \\
\hline Membangun Wira Usaha Mandiri Pangan & $\begin{array}{l}\text { Pelatihan dan pembinaan untuk membangun wira usaha } \\
\text { mandiri }\end{array}$ \\
\hline
\end{tabular}

beberapa permasalahan yang akan dipecahkan bersama. Metode yang digunakan dalam pemecahan masalah ini dilakukan secara parsitipatif, tutorial, pendampingan, pelatihan, dan demplot dilokasi Kelompok Mitra. Permasalahan mitra dan solusinya secara spesifik disajikan pada Tabel 4.

Hasil kesepakatan antara mitra dengan tim pengabdi menghasilkan titik temu permasalahan yang diselesaikan untuk penyesuaian antara keingingan pengabdi dengan mitra sehingga dicapai optimalitas. Khususnya berkaitan aspek produksi olahan kentang menjadi donut kentang.

\section{Metode Ilmiah}

\section{Pengelolaan Nilai Tambah Hasil Usaha dan Nilai Gizi Produk Pangan}

Pengolahan produk pangan berbasis tanaman kentang menjadi donat kentang terdapat berbagai unsur-unsur penting yang terkandung pada kentang (Krisnamurthi, 2010; Rini et al., 2021), adalah seperti yang dijelaskan Tabel 5 dibawah ini.

Penilaian unit usaha minimal menghasilkan titik impas atau kesamaan antara pengeluaran biaya dengan hasil yang diterima atas usaha tersebut (Break Event Point -BEP). Hasil usaha akan dinyatakan mendapat keuntungan bilamana penerimaan yang diterima relatif lebih besar dibandingkan dengan biaya yang dikeluarkan dan terjadi kerugian bilamana terjadi kondisi sebaliknya.

Peningkatan pendapatan dari keuntungan yang didapat bisa digunakan untuk peningkatan kesejahteraan. Selain itu, dengan meningkatnya nilai pendapatan, diharapkan juga meningkatkan pemenuhan gizi. Tinjauan makro dan mikro atas gizi masyarakat

Tabel 5. Analisis Bahan Makanan yang Terkandung pada Donat Kentang (per 100 gram)

\begin{tabular}{lcccccccccccc}
\hline $\begin{array}{l}\text { Nama } \\
\text { Bahan }\end{array}$ & $\begin{array}{c}\text { Air } \\
\mathbf{g \%}\end{array}$ & $\begin{array}{c}\text { Energi } \\
\text { kal }\end{array}$ & $\begin{array}{c}\text { Protein } \\
\mathbf{g} \%\end{array}$ & $\begin{array}{c}\text { Lemak } \\
\mathbf{g} \%\end{array}$ & $\begin{array}{c}\text { Karbon } \\
\mathbf{g \%}\end{array}$ & $\begin{array}{c}\mathbf{C a} \\
\mathbf{M g} \\
\mathbf{\%}\end{array}$ & $\begin{array}{c}\mathbf{P} \\
\mathbf{M g} \\
\mathbf{\%}\end{array}$ & $\begin{array}{c}\mathbf{F e} \\
\mathbf{M g} \\
\mathbf{\%}\end{array}$ & $\begin{array}{c}\text { Vit A } \\
\mathbf{A I} / \mathbf{1 0 0 g}\end{array}$ & $\begin{array}{c}\text { Vit } \\
\mathbf{B m g} \\
\mathbf{\%}\end{array}$ & $\begin{array}{c}\text { VitC } \\
\mathbf{M g} \\
\mathbf{\%}\end{array}$ & $\begin{array}{c}\text { Bjdd } \\
\mathbf{G} \\
\mathbf{\%}\end{array}$ \\
\hline Kentang & 78 & 83 & 2,0 & 0,1 & $\mathrm{Mg} \%$ & 11 & 56 & 0,7 & 0 & 0,11 & 17 & 0,85 \\
\hline $\begin{array}{l}\text { Kuning } \\
\text { telur } \\
\text { ayam }\end{array}$ & 49 & 36 & 16.3 & 31.9 & 0.7 & 147 & 586 & 7.2 & 2000 & 0.27 & 0 & 100 \\
\hline $\begin{array}{l}\text { Tepung } \\
\text { terigu }\end{array}$ & 12 & 365 & 8.9 & 1.3 & 77.3 & 16 & 106 & 1.2 & 0 & 0.12 & 0 & 100 \\
\hline Mentega & 17 & 725 & 0.5 & 81.6 & 1.4 & 15 & 16 & 0.1 & 3300 & 0 & 0 & 100 \\
\hline
\end{tabular}


berkaitan dengan kondisi masyarakat secara keseluruhan (tinjauan makro) dan gizi individu (tinjauan mikro). Terdapat hubungan yang kuat antara gaya hidup keluarga, masyarakat dan perorangan keluarga.

\section{Standar Operasional Prosedur Pembuatan Donat Kentang \\ Cara pembuatan Kue Donat} Kentang, (a) sediakan bahan 2 batang kentang manis, tepung terigu $1 / 4 \mathrm{~kg}$, gula putih 2 sendok sesuaikan selera, pernipan satu sendok makan, garam secukupnya, mentega satu sendok dan satu butir telur. (b) prosedur pembuatan kue donat kentang adalah sebagai berikut; kentang yang sudah dikupas lalu dikukus dan dilembutkan, selanjutnya dibuatkan adonan yang terdiri dari pernipan dengan air hangat dua sendok makan hingga mengembang, selanjutnya masukan tepung terigu, gula, dan garam secukupnya, lalu diaduk hingga rata. Setelah itu, masukan mentega dan telur, dicampurkan dengan kentang yang sudah dilembutkan. Aduk hingga kalis (atau tidak lengket ditangan) dan tutup dengan plastik hingga mengembang (dibutuhkan waktu 20 menit). (c) setelah mengembang maka dilakukan pencetakan sesuai dengan selera (dibiarkan beberapa menit agar mengembang); (d) sediakan wajan beserta minyak secukupnya untuk menggoreng donat. (e) taburi donat yang sudah digoreng dengan aneka macam rasa pilihan selera (bisa keju, kacang, meses, strawberry, atau lainya dengan catatan diolesi mentega sebelumnya).

Dengan dikuasai dan diterapkannya SOP ini, maka target yang akan dicapai adalah mitra masyarakat desa dapat membuat Donat Ketang yang bergizi dan menambah pendapatan mitra, serta penguatan ketahanan pangan.

\section{Penentuan Break Even Point}

Penentuan berapa besarnya produksi yang dihasilkan sehingga tercapai posisi titik impas, artinya bila produksi yang dihasilkan melebihi produksi pada titik impas, maka usaha tersebut akan mendatangkan keuntungan (Gjergji et al., 2021; Krouse, 1993). Besarnya produksi yang dihasilkan dengan kuantintas produksi titik impas terjadi ketika dicapai rasio antara biaya tetap dengan selisih antara harga dengan biaya variable. Bila $\mathrm{P}=$ harga penjualan per unit; $\mathrm{Q}=$ kuantintas yang dihasilkan dan dijual, $\mathrm{FC}=$ fixed cost, $\mathrm{VC}=$ variabel cost; secara matematis dirumuskan melalui rumus $\mathrm{Q}=\mathrm{FC} /(\mathrm{P}-\mathrm{VC}) \ldots(1)$, jika dikaitkan dengan besarnya penjualan (sales) output; $\mathrm{P} * \mathrm{Q}=\mathrm{TFC}+(\mathrm{TVC} / \mathrm{sales})$ * sales...(2). Pada posisi titik impas, maka penjualan akan sama dengan dengan besarnya biaya yang dikeluarkan, yaitu: Sales $=$ TFC $+(\text { TVC/sales })^{*}$ sales.

$$
\text { Sales }\left(1-\frac{T V C}{\text { sales }}\right)=T F C \text {...(3), }
$$

sehingga penjualan pada titik break even point sebesar sales $=\frac{T F C}{\left(1-\frac{T V C}{\text { sales }}\right)}=$ artinya besarnya penjualan sebagai rasio dari total biaya tetap terhadap selisih satu terhadap rasio total biaya variabel terhadap penjualan. Penghitungan titik impas dari sisi besaran volume penjualan (sales volume) dirumuskan sebagai berikut Bep (sales volume) $=$

$$
\frac{\text { total fixed cost }}{1-\frac{\text { total variable cost }}{\text { total sales volume }}}=\frac{F C}{1-\frac{V C}{P Q}} \ldots(4) \text {. }
$$

\section{Harga yang Diterapkan agar Keuntungan Maksimum}

Produsen rasional, akan bekerja pada titik Profit maksimum, berapa besarnya perubahan produksi yang harus dilakukanagartercapai situasikeuntungan maksimum (Gjergji et al., 2021; Krouse, 1993). Diferensiasi pertama dari fungsi keuntungan terhadap perubahan output akan mencapai titik optimum, ketika turunan pertamanya sama dengan nol atau bisa juga dinyatakan ketika MR (Marginal Revenue) sama dengan MC (Marginal Cost). MR sebagai cerminan berapa besarnya perubahan penjualan 
ketika terjadi perubahan output yang dihasilkan dan laku terjual, bila kondisi demikian dikatikan dengan harga barang yang dihasilkan serta respon permintaan konsumen terhadap perubahan harga barang tersebut atau Elastisitas Harga permintaan (ed), keterkaitan tersebut dirumuskan sebagai berikut : (lihat catatan sebelumnya) $M R=P\left(1-\frac{1}{e d}\right), \ldots(5)$, bila dikondisikan pasar berada pada situasi persaingan sempurna dengan elastistitas tak terhingga, sehingga harga sama dengan penerimaan marginalnya.

Penetapan harga untuk produk pada situasi persaingan sempurna sebesar biaya marginalnya. Posisi keuntungan maksimum dimana $\mathrm{MR}=\mathrm{MC}$...(6) ini berarti besarnya keuntungan maksimum, ketika ingin mengkaitkan antara unsur harga dengan besarnya biaya marginal, maka dirumuskan $M C=P\left(1-\frac{1}{e d}\right) \ldots(7)$, atau bisa dituliskan $\frac{P-M C}{P}=\frac{1}{e d} \ldots$ (8) dari rumus ini juga dapat dibuatkan bahwa penentuan harga dari hasil produksi yang menghasilkan keuntungan maksimum adalah sebagai berikut ini;

$$
P=M C \cdot \frac{e_{d}}{e_{d}-1} \ldots \text { (9) }
$$

ini merupakan tujuan jangka pendek (short run profit) dengan menerapkan pendekatan marginalitas $(\mathrm{MR}=\mathrm{MC})$, namun dalam tujuan maksimisasi keuntungan jangka panjang, biasanya perusahaan/unit usaha akan menerapkan harga barang/komoditasnya pada situasi atau pendekatan average cost principle (prinsip biaya rata-rata), jadi unit usaha tidak menetapkan harga pada saat marginal revenue berpotongan dengan marginal cost, namun menetapkan harga pada situasi dimana harga (price) akan menutupi biaya variabel rata-rata (average variable cost AVC), biaya tetap rata-rata (Average Fixed Cost AFC), dan keuntungan normal profit margin (biasanya 10 persen). Kondisi tersebut dirumuskan sebagai berikut.

$\mathrm{P}=\mathrm{AVC}+\mathrm{AFC}+$ profit Margin,...(10) atau $\mathrm{P}=\mathrm{AC}+$ profit margin...(11).

\section{Metode Pelaksanaan}

Adapun metode pelaksanaan kegiatan dilakukan dengan berbagai aktivitas yang dapat dijelaskan sebagai berikut, dimana aktivitas pengabdian, metode kegiatan, indikator capaian serta variabel yang ingin dicapai disajikan sebagai berikut.

Tahap I. Tinjauan survei awal atau penjajakan pada mitra berkait potensi dan permasalahan mitra untuk dapat dicarikan penyelesaian terbaik, dimana mitra terpilih adalah petani dan ibu rumah tangga, petani dengan tanaman yang ditanam adalah kentang dengan metode pemasaran dalam bentuk mentahan. Oleh karena itu, penyuluhan awal pada mitra berkait nilai gizi dari kentang yang sangat potensial dan beberapa alternatif pengolahan pangan yang dapat digunakan sebagai sajian diversifikasi pangan keluarga. Pada tahap berikutnya dapat dimanfaatkan untuk lahan bisnis (wirausaha) yang menjanjikan nilai

Tabel 6. Metode Kegiatan dan Indikator Capaian

\begin{tabular}{llll}
\hline \multicolumn{1}{c}{ Aktivitas Pengabdian } & \multicolumn{1}{c}{ Metode Kegiatan } & \multicolumn{1}{c}{ Indikator Capaian } & \multicolumn{1}{c}{ Variabel } \\
\hline Penyuluhan & $\begin{array}{l}\text { Diskusi dan program } \\
\text { penyuluhan langsung }\end{array}$ & $\begin{array}{l}\text { Besaran frekuensi } \\
\text { penyuluhan yang } \\
\text { dilakukan per bulan }\end{array}$ & $\begin{array}{l}\text { Jumlah penyuluhan yang } \\
\text { dilakukan }\end{array}$ \\
\hline $\begin{array}{l}\text { Dimensi produksi donut } \\
\text { kentang }\end{array}$ & $\begin{array}{l}\text { Praktik langsung melalui } \\
\text { pemilihan bahan yang } \\
\text { dibutuhkan }\end{array}$ & $\begin{array}{l}\text { Dihasilkan kuantitas } \\
\text { satu kali produksi } \\
\text { dan komposisi standar } \\
\text { pembuatan donut kentang }\end{array}$ & $\begin{array}{l}\text { Jumlah donut kentang } \\
\text { yang dihasilkan setiap satu } \\
\text { proses produksi }\end{array}$ \\
\hline $\begin{array}{l}\text { Dimensi Pemasaran } \\
\text { Produksi }\end{array}$ & $\begin{array}{l}\text { Demonstrasi dan } \\
\text { penyuluhan }\end{array}$ & $\begin{array}{l}\text { Jenis/model pemasaran } \\
\text { yang dikembangkan }\end{array}$ & $\begin{array}{l}\text { Model bentuk pemasaran } \\
\text { atas produk yang } \\
\text { dihasilkan }\end{array}$ \\
\hline
\end{tabular}


tambah penghasilan bagi keluarga. Tahap II, Pelatihan/praktik langsung pembuatan produk pangan olahan berbasis kentang, yaitu donut kentang. Tahap III, Penyuluhan berkait dengan upayaupaya optimalisasi pemasaran produk pangan olahan kentang, sehingga dapat meningkatkann nilai tambah penghasilan keluarga.

Adapun rangkaian tahapan dan indikator capaian yang diharapkan, serta variabel target yang ingin dicapai disajikan dalam Tabel 6.

\section{Hasil dan Pembahasan}

Kegiatan pengabdian dilakukan pada tanggal 13 September 2020, berlokasi pada mitra beralamatkan Jalan Tirto Taruno, Dusun Klandungan,

Tabel 7. Evaluasi dan Monitoring Kegiatan Pengabdian

\begin{tabular}{crll}
\hline No. & Kriteria & Indikator pencapaian & Hasil Capaian \\
\hline 1 & Penyuluhan & $\begin{array}{l}\text { Besaran frekuensi penyuluhan } \\
\text { yang dilakukan per bulan }\end{array}$ & Penyuluhan yang dilakukan satu kali
\end{tabular}

\begin{tabular}{|c|c|c|c|}
\hline 2 & Dimensi Produksi & $\begin{array}{l}\text { Dihasilkan kuantitas satu kali } \\
\text { produksi dan komposisi standar } \\
\text { pembuatan donut kentang }\end{array}$ & 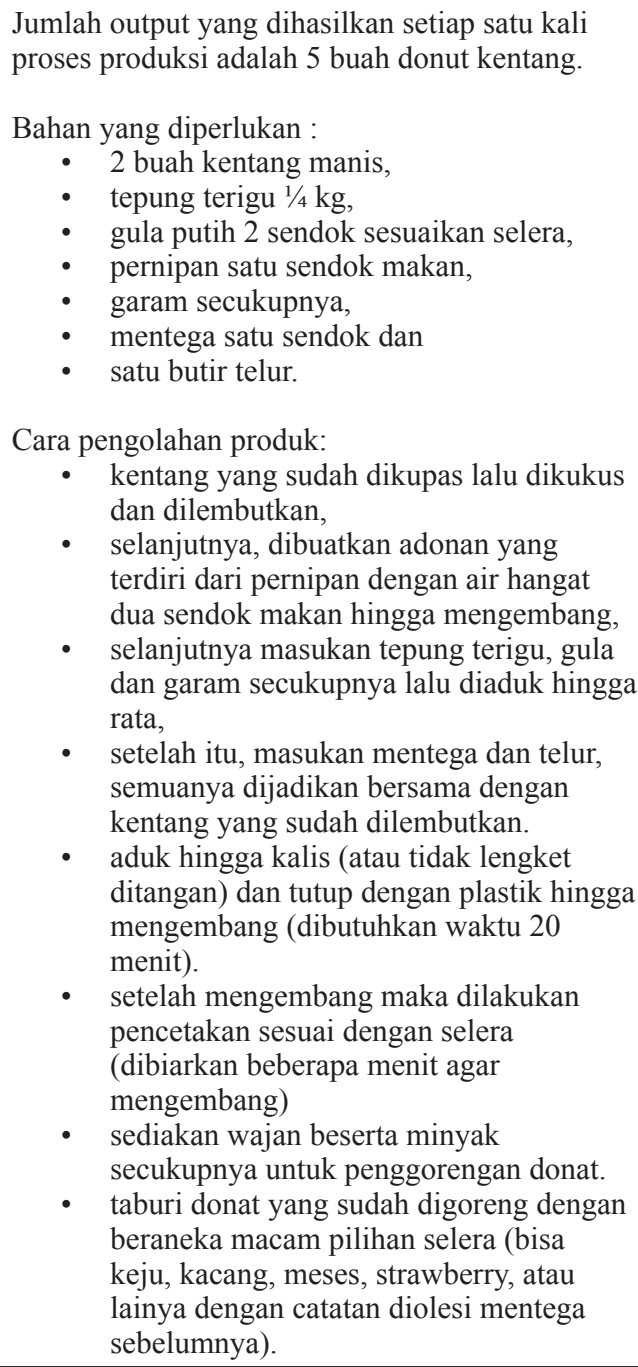 \\
\hline 3 & $\begin{array}{l}\text { Dimensi Pemasaran } \\
\text { Produksi }\end{array}$ & $\begin{array}{l}\text { Jenis/model pemasaran yang } \\
\text { dikembangkan }\end{array}$ & $\begin{array}{l}\text { Pemasaran dilakukan dengan metode konsinyasi } \\
\text { atau di jual mandiri pada rumah warga masing- } \\
\text { masing }\end{array}$ \\
\hline
\end{tabular}


Landungsari, Kec. Dau, Kab. Malang. Hasil dari monitoring kegiatan pengabdian disajikan dalam Tabel 7.

\section{Kesimpulan dan Saran}

\section{Kesimpulan}

Kegiatan pengabdian masyarakat dilakukan dengan pendekatan praktik langsung pembuatan produk berbasis kentang di salah satu rumah warga yang beralamatkan di Jalan Tirto Taruno, Dusun Klandungan, Landungsari, Kec. Dau, Kab. Malang. Pemilihan dusun didasarkan atas kondisi yang telah dibahas sebelumnya pada analisis situasi dan permalahan mitra dimana dengan dasar kehidupan berbasis sektor pertanian, dengan waktu tunggu antara masa tanam dan panen cukup lama, maka diperlukanya kreativitas dan produktivitas untuk mengisi peluang waktu tunggu tersebut yang diisi dengan kegiatan produktif, baik sebagai upaya peningkatan pendapatan maupun upaya diversifikasi produk makanan, dalam hal ini pembuatan wirausaha donat kentang.

Sebagai upaya untuk penguatan ketahanan pangan yang dalam penerapannya diperlukan ketersediaan pangan, akses terhadap pangan dan penghasilan, pemanfaatan atau penyerapan pangan, serta kerentanan pangan. Faktor akses terhadap pangan dan penghasilan perlu dikedepankan untuk menaikkan daya beli masyarakat desa melalui wirausaha pembuatan produk pangan olahan kentang. Profil mitra terpilih dengan mata pencarian buruh dan petani musiman diharapkan mampu memahami pengetahuan didalam pembuatan produk pengolahan kentang yang berdampak kepada multi-income atau peningkatan pendapatan keluarga.

Diversifikasi kemampuan atau skill dalam bidang pengolahan pangan menjadi kebutuhan penting dan strategis sebagai upaya pemenuhan kebutuhan keseharian atas pangan bergizi, serta memanfaatkan lebih banyak ketersediaan sumber lokal. Demikian pula dengan pemenuhan pangan untuk warga masyarakat desa diperlukan kepandaian dalam pengolahan pangan untuk pemenuhan gizi standar serta diversifikasi ketersediaan pangan dan sekaligus wahana untuk pengembangan wirausaha. Pengolahan lebih lanjut bahan dasar pangan dari produk kentang tersebut menjadi berbagai macam jenis olahan pangan yang tentunya akan meningkatkan dan membangun selera makan serta kandungan gizi yang meningkat dan mampu dikembangkan lebih lanjut sebagai kegiatan berwirausaha dalam peningkatan pendapatan sebagai sumber alternatif pengembangan kelembagaan lebih lanjut. Diantara sejumlah produk olahan berbasis kentang yang dimaksud, yaitu produk donut kentang.

\section{Saran}

Pemantapan pangan dan peningkatan pemenuhan gizi menjadi langkah strategis, keaneka ragaman pangan diharapkan mampu menunjang program diversifikasi pangan, khususnya kebutuhan pangan masyarakat pedesaan. Produk pangan berbasis "kentang" untuk memenuhi variasi kebutuhan masyarakat desa, boleh jadi menjadi produk pangan utama di pedesaan. Khusus untuk warga pedesaan yang menjadikan tempe dan Tahu sebagai menu utama dalam hidangan pangan sehari-hari masyarakat pedesaan, sehingga kentang menjadi produk substitusi dan pelengkap. Oleh karena itu, keanekaragaman pangan berbasis produk "kentang" memiliki nilai keutamaan, salah satu alternatif mengembangkan sumber wirausaha. Di sisi yang lain, upaya diversifikasi pangan dan peningkatan gizi sekaligus dapat digunakan sebagai media untuk meningkatan tingkat penghasilan. Maka diharapkan kedepan kegiatan berwirausaha akan terus berjalan karena sebagian besar mata pencarian mengandalkan pada pertanian yang terbatas dengan tenggang waktu antara 
tanam dan panen, maka ada waktu luang tersebut yang akan menjadi berdaya guna bila digunakan untuk aktivitas produktif (berwirausaha).

\section{DAFTAR PUSTAKA}

Fitrianingrum, F., \& Aulia, B. U. (2018). Penentuan Lokasi Agroindustri Berbasis Komoditas Jagung di Kabupaten Jombang. Jurnal Teknik ITS, 7(2), C100-C106.

Gjergji, R., Vena, L., Sciascia, S., \& Cortesi, A. (2021). The effects of environmental, social and governance disclosure on the cost of capital in small and medium enterprises: The role of family business status. Business Strategy and the Environment, 30(1), 683693.

Huriani, Y., Dulwahab, E., \& Annibras, N. (2021). Strategi Penguatan Ekonomi Perempuan Berbasis Keluarga. Lekkas.

Ihsan, M., Firza, E., Edward, E., Firmansyah, F., \& Abdullah, Z. (2021). Ketahanan Pangan Nasional Melalui Diversifikasi Olahan Kentang Kayu Aro. Jurnal Karya Abdi Masyarakat, 5(1), 8995.

Krisnamurthi, B. (2010). Manfaat Jagung dan Peran Produk Bioteknologi Serealia dalam Menghadapi Krisis Pangan, Pakan dan Energi di Indonesia. Prosiding Pekan Serealia Nasional, 1-9.

Krouse, C. G. (1993). Competitive advantage, cost of capital and the financial relationship system in Japan. Journal of Institutional and Theoretical Economics (JITE)/ Zeitschrift Für Die Gesamte Staatswissenschaft, 634-655.

Kurnianingsih, R., Sukenti, K., \& Julisaniah, N. I. (2021). Diversifikasi Pengolahan Kacang Lokal Lombok Menjadi Pangan Fungsional Di Desa
Ubung Lombok Tengah. Jurnal Pengabdian Magister Pendidikan IPA, 4(4), 285-289.

Kusmayadi, A., Sundari, R. S., \& Sumaryana, Y. (2021). INOVASI TELUR ASIN ASAP PEDAS SEBAGAI PRODUK DIVERSIFIKASI PANGAN UNGGULAN DESA SUKANAGALIH KABUPATEN TASIKMALAYA. LOGISTAJurnal Ilmiah Pengabdian Kepada Masyarakat, 5(1), 285-290.

Rini, B., Azima, F., Sayuti, K., Novelina, N., Yenrina, R., Nazir, N., Anggraini, T., Hasbullah, H., Aisman, A., \& Syukri, D. (2021). PENYULUHAN, PELATIHAN, DAN PERAGAAN PROSES PENGOLAHAN KENTANG MENJADI BERBAGAI PRODUK PANGAN KOMERSIL. LOGISTA-Jurnal Ilmiah Pengabdian Kepada Masyarakat, 5(1), 248-252.

Santosa, D. (2021). PEMANFAATAN SUMBER DAYA ALTERNATIF UNTUK KEMANDIRIAN PANGAN DI KELURAHAN GUNUNG TANDALA TASIKMALAYA. Ethos, 9(2), 260-266.

Syairozi, M. I. (2021). ANALISIS KEMISKINAN DI SEKTOR PERTANIAN (Studi Kasus Komoditas Padi di Kabupaten Malang). Media Ekonomi, 28(2), 113-128.

Syarifuddin, A., Dirpan, A., Rukka, R. M., \& Latief, R. (2020). PEMBERDAYAAN IBU RUMAH TANGGA DI DESA TALABANGI MELALUI KEGIATAN DIVERSIFIKASI PANGAN OLAHAN BERBASIS PISANG. Jurnal Dinamika Pengabdian (JDP), 5(2), 227-237.

Wicaksono, A. P. N., \& Soelistyo, A. (2020). IBM-Diversifikasi Produk Jagung Menjadi Produk Puding 
Jagung dan Ice Cream Jagung.

ETHOS: Jurnal Penelitian Dan

Pengabdian Kepada Masyarakat,

8(2), 212-220. 